\title{
ACADEMIC AND PROFESSIONAL REQUIREMENTS, ETHICAL CONSIDERATIONS AND SKILLS IN THE APPLICATION OF INDUSTRIAL PSYCHOLOGICAL KNOWLEDGE*
}

\author{
A.B. BOSHOFF and ELZA HAMBLIN \\ GRADUATE SCHOOL OF BUSINESS \\ UNIVERSITY OF PRETORIA
}

\begin{abstract}
OPSOMMING
Die operasionele veld van die Bedryfsielkunde in Suid-Afrika stel besondere eise aan die beoefenaars van die professie. Omstandighede wil dit dikwels dat die bedryfsielkundige hoofsaaklik ' $n$ besoldigde werknemer van 'n groot organisasie is en dus onderworpe is aan die politieke druk inherent in so 'n situasie. Dit op sigself stel hoë eise aan sy integriteit en maak 'n periodieke besinning oor die wese van sy werk noodsaaklik. Met professionalisme as uitgangspunt ondersoek die skrywers die aard van die probleme wat die bedryfsielkunde in die organisasie ondervind en die veranderende aard van sy rol binne die organisatoriese struktuur. Dit word gevolg deur ' $n$ noukeurige omskrywing van die kennis en vaardighede wat van die bedryfsielkunde vereis word. Ten slotte word oorweging geskenk aan sekere moontlike veranderinge in die opleiding van voornemende professionele bedryfsielkundiges.
\end{abstract}

The industrial psychologist must necessarily practice his profession in an organizational milieu and the historical development of the profession in South Africa has placed industrial psychologists of the seventies most often in the position of paid employment, bound to one organizational "client". The result in many cases is constrained autonomy, pressure on professional integrity and role demands for which the incumbent is academically ill-prepared.

The situation is complex and if industrial psychologists are to clearly perceive the road ahead and meet the professional challenge of the future successfully, an analysis is needed which will identify and examine the nature of the problems involved and consider possible action plans.

\footnotetext{
* Based on a paper read before industrial psychologists at the Teachers' Training Programme for Southern Africa in Pretoria, 15th-17th September 1976.
} 
An approach is suggested here which seeks to analyze the situation in terms of (a) the characteristics of professions and professional work, (b) the values adhered to in science, (c) the characteristics of organizations, and (d) the implications for industrial psychologists.

\section{THE CHARACTERISTICS OF PROFESSIONS AND PROFESSIONAL WORK}

A "profession" according to Shepard (1962, p.353), involves service or ministery rendered out of specialized knowledge, high standards of conduct and a kind of democracy as the means of social control over its members.

The key element of Shepard's concept seems to be specialized knowledge. If it were not for specialized knowledge, high standards of conduct would be irrelevant and there would be no need for any form of social control, i.e. professional ethics: anyone would be able to detect self interest actions in the place of service to others. Without specialized knowledge there would be no binding common denominator, linking individual practitioners to each other and there would be no reputation for reliability to protect.

According to this view it is specialized knowledge upon which a profession rests. But if the knowledge is not applied in the service of others, there would be little common interest to protect. In its application, specialized knowledge becomes a real asset and permits its possessor to earn a living, conforming to Schein's $(1972$, p.8) view of a professional as an individual engaged in a full-time occupation that provides his principle source of income.

The practitioner's capacity for selling his services rests not only on his personal capabilities in the application of his specialized knowledge, but on the reputation of practitioners in general to provide satisfactory results in their specialized ministration to clients. Should individuals purport to have the relevant specialized knowledge and yet show themselves incapable to fulfilling client expectations, the credibility of all in the profession is jeopardised.

As professionals they thus have a real interest to protect and tend to form associations of one form or another of which membership is exclusive and entry governed by proof of knowledge and competence in application.

The misapplication of purported specialized knowledge in some areas carries obvious and severe consequences and in the public interest, society itself would create, through legislation, an association, membership of which would be compulsory in order to practice at all. 
Conditions of membership might then be prescribed and controlled by a governing body. Along with "specialized knowledge", however, go two related concepts namely commitment and responsibility.

According to Kornhauser (1963, p.1) "professional commitment is based on the belief that the development and exercise of expertise is worthy of the devotion of a life time and carries its own reward. Professional responsibility is based on the belief that the power conferred by expertise entails a fiduciary relationship to society". These observations of Kornhauser point in the direction of fundamental professional norms concerning personal objectives and self imposed constraints and are critical in establishing the interrelationships between each profession and its task environment.

Schein (1972, p.9) acknowledges these points made about professionalization and arrives at the conclusion that the ultimate intention of professionalization is the achievement of "autonomy" which implies:

- $\quad$ "knowing better what is good for the client than anyone else because of extended technical education and training

- $\quad$ subjecting one's decisions only to the review of colleagues and setting all one's standards pertaining to jurisdiction of the profession and entry into it through peergroup associations."

In a stimulating book Schein (1972) outlines a great number of changes affecting the professions, some of which seem to be relevant to industrial psychologists. A partial list of the changes affecting industrial psychologists are:

- New clients - industrial psychologists are mainly employed in various kinds of organizations and relatively few work as autonomous professionals. A significant number are being paid by some combination of salary and fees.

- New concepts are emerging about who the clients of professionals are. Entire organizations are more and more acting as purchasers of the services of industrial psychologists . We are also creating new "clients" although the consumer certainly does not see himself as a client. It becomes necessary to accommodate ourselves to the situation where we are dealing with multiple client systems and deal with projects in which conflict between parts of the client system is created. 
- More knowledge brings with it more specialities and subspecialities differentiation. This makes integration of newly developed knowledge both difficult and necessary. Increased specialization further seems to bring with it the dangers of obsolescence, conflict between subspecialities, etc.

- $\quad$ The role of industrial psychologists may be changing or should possibly be changing. In a pluralistic society attention should possibly be focused on working for what Schein (1972, p.25) calls "the poor and the powerless".

\section{THE VALUES ADHERED TO IN SCIENCE}

In order to investigate the situation in which the professional applies his knowledge it is necessary to pause at the values that are pursued in science and that must be kept in mind during the practice of a science.

Shils (1962, p.610) sees science as a body of systematized knowledge gathered in a pluralistic society. In order to apply specialized knowledge it is clearly necessary to systematize the knowledge and with professional roots in science, the values must form the basis of the values of all the professions.

According to Parsons (1962, p.593), the dominant standard of science is that of objective, impartial truth and accordingly the search for truth should lie uppermost in the minds of the members and governing bodies of professional associations. Truth cannot be treated as parochial but it is likely that it may be integrated with other acceptable universalistic values that justifies the recognition of its existence. Science is integrated with a value system in such a way that many of the basic values with which it is associated and which will determine these ends, are not arbitrary but are inherent.

Sarton (1956, p.177) explicitly illustrates that "the whole fabric of science seems thus to be growing like a tree; in both cases the dependence upon the environment is obvious enough, yet the main cause of growth - the growth pressure, the urge to grow - is inside the tree, not outside".

Systematized knowledge, truth and an inherent growth potential, therefore, are the corner stores of scientific endeavour. Having adopted and behaving according to such basic principles, however, the scientist faces a rather unsympathetic, practical, if not pragmatic, world in which he has to hold his own. 


\section{THE CHARACTERISTICS OF ORGANIZATIONS}

If industrial psychologists are working in organizations it may be worthwhile to take a brief look at the characteristics of organizations and the processes operating in organizations.

Classical writers see the organization as a completely logical entity operating in a risky environment with full knowledge of relevant information and according to prescribed rules. This does not seem to be congruent with the reality as described by Cyert and March (1963), Mintzberg (1973), Thompson (1976), March and Simon (1958) and others.

Cyert and March (1963, p.117) see organizational processes as having the following characteristics:

\section{Quasi - resolution of conflict}

Organizations are described as consisting of changing coalitions resulting in local rationality, i.e. subunits handle a limited set of problems and a limited set of goals. This is given consistency through the use of "acceptable level" decision rules and sequential attention to goals.

A somewhat similar formulation of organizational decision making is given by March and Simon (1958, p.140) who indicate that organizations tend to "satisfice" rather than "optimize". This seems to indicate the same concept as "acceptable level" decision rules.

\section{Avoidance of uncertainty}

Organizations constantly strive towards risk-avoidance by "negotiating" their environments so as to create situations where "good business practice", budgeting systems and negotiated price structures limit risk to the maximum possible degree.

\section{Problemistic search}

It seems as if in their search for solutions to problems organizations tend to limit their search to the specific, immediate problem at hand. It seems as if planned systematic scanning of the environment should be regarded as the exception.

The search activity carried out by organizations is furthermore "simple-minded" that is, it is limited to the environment of the symptom or symptoms of the problem. The search activity is carried out in the environment of the present, easily available alternative. This is 
changed if the present alternative very obviously does not solve the problem. Only if this does not work, a wider search will be carried out, for instance, into the use of knowledge which cannot show its ability to make a direct contribution to the objectives and goals as determined by the organization.

The search activity of organizations is, to complicate matters, also biased. This is caused by specific, unbalanced training and experience in different parts of the organization. The interaction of hope and expectation in members of the organization and communication biases frequently result in unresolved conflict in the organization.

It seems as if the description given by these authors can be correlated with Mintzberg's (1973) views about how managers really function in organizations, in contrast with how the functioning is commonly described.

Mintzberg (1973) says top managers typically:

- $\quad$ have to do a great amount of work at an unrelenting pace;

- do work characterized by brevity and discontinuity;

- give preference to verbal in contrast to written communication resulting in a very large percentage of total time spent in meetings and interaction with other people;

- $\quad$ prefer matters that are current and which can be solved with short process decision making.

From the above it can be inferred that Thompson's (1967) views serve as a good description of how an organization functions.

According to Thompson, (op.cit.) the objectives of the modern large organization are the negotiated settlements of the dominant coalition and this settlement is fixed only as long as the dominant coalition is stable and the task environment undisturbed. The strategic level of decision making in terms of the politically determined objectives can of course be elaborated at the management control and operational levels of decision making. To the extent to which the operative decision criteria employed at points of action are congruent with the company objectives, power has been retained in the hands of the dominant coalition. This is probably the ideal situation in terms of organizational effectiveness. However, as has been indicated by many, there are usually those, lower in the hierarchy who are ambitious or those who fear displacement from those below or in horizontal relationships. The competition struggle for ascending results, sooner or later result in reduced goal congruency and there will be a 
tendency for those effected to award themselves with loyal rather than effective subordinates. It is easy to win a man's "loyalty" by favouring him with promotion over those more able. The political struggle of the organization thus leads to a conflict between particularistic and universalistic criteria in the appraisal of subordinates.

And into this seething mass of human aspirations a dagger thrusts an industrial psychologist in search of autonomy, truth and ideal solutions! It will not be long before he becomes a pawn to be manipulated in power struggles. To be a docile dog or a fiercy firee that is the question - or is it not?

\section{THE ROLE OF THE INDUSTRIAL PSYCHOLOGIST}

- Industrial Psychology as a profession, rests on a considerable body of specialized knowledge and the quantity and quality of research within the profession reflects an abiding concern for truth. Associations exist in many parts of the world which maintain high standards of entry. Yet, despite these professional strengths, the ranks of industrial psychologists the world over are not united on the subject of application of knowledge and ethical standards.

The expert power inherent in most professions is sadly lacking for the industrial psychologist; everyone is an "amateur psychologist" and knows all there is to know about understanding people and motivating them. It is difficult to prove to the managing director how little he knows without losing a client or employer.

At the other end of the scale there are those very perceptive but perhaps rather unscrupulous businessmen who acknowledge their own limitations, recognize the value of the industrial psychologist's specialized knowledge and seek to use this knowledge to exploit elements of the company's task environment. In such circumstances the clash between personal and professional ethics on the one hand and explicitly or implicitly stated company objectives on the other may be intolerable.

- The industrial psychologist must surely be well placed to recognize the futility of fighting existing powers while realizing that the only way of ensuring a 
meaningful contribution (in terms of improved human effectiveness in organizations) on his part is by himself playing a political game - and seeking to gather power and influence in projecting his own ideas into or through the dominant coalition, thus finding realization in changed company objectives.

- The industrial psychologist must on the other hand necessarily play a mediating role in the modern firm. Communicating with consumers through advertising and bargaining with organized labour are two obvious areas where this role is manifest. $\mathrm{He}$ is expected today, not only to analyse problems, drawing on his expert knowledge, but to become personally involved in the resolution of those problems. Whether the decisions he acts on are his own or those of others reflect the extent to which he has autonomy of judgement in the organizational context. In either event he is expected to possess negotiating skills. Even in the more traditional task of counselling individuals, the industrial psychologist should possess negotiating skills largely based in persuasion.

- Given the political nature of the determination of objectives, it is only natural that in order to maximize his effectiveness, the first thing the industrial psychologist should do on joining his organization is to overcome the limits of his position defined status by identifying and negotiating with one or more members of the dominant coalition.

- The consultant industrial psychologist would not have to overcome any position defined limitations and can immediately negotiate with one of the policy makers thus inherently enjoying more flexibility than his employed colleague. On the other hand, the implementation of recommendations made by consultants is not easily controlled by the consultants over a period of time and a good decision could easily be made to appear ridiculous by saboteurs in opposition.

- It is in the implementation of the industrial psychologist's recommendations that many problems crop up. The very nature of his work implies that any decision will involve changes for people and it is well known that people resist change. As a change agent, therefore, the industrial psychologist must endeavour to anticipate 
the reactions of others to changes and to structure his activities to ensure a peaceful transition. Against the background of political infighting, this inevitably becomes a task of no mean proportions.

From the above it is clear that to be successful an industrial psychologist must clearly possess superior bargaining skills, many of which can be learned formally.

Schein $(1972$, p.21) states that problems which previously were not even acknowledged as legitimate in the domain of a given profession are now being recognized and defined as legitimate and important areas of concern. This is certainly true for industrial psychology: negotiating is part and parcel of the fundamental content of the profession. Bass (1970, p. 208) has already pointed to the need for the personnel psychologist to be sensitive to larger organizational and social issues while developing programmes in recruiting, selection and training. It is suggested that this sensitivity is needed so that the timing and structure of bargaining ploys can be appropriate.

It must, of course, be acknowledged that the industrial psychologist who is skilled in the arts of negotiation will often be able to negotiate himself into the top executive position of his organization. Under such circumstances the individual would need to decide for himself whether he wishes to remain a professional expert industrial psychologist or take up the reigns of top management as an industrial psychologist.

Three complementary avenues are deemed necessary for ensuring that the benefits of specified knowledge in the field of industrial psychology are more fully enjoyed by business organizations in South Africa.

With regard to the first, which is university training, consider the following comments of Douglas W. Bray (1970, p.212) of the American Telephone and Telegraph Company, concerning the position in the United States:

"It is my observation that most of the young men applying for jobs in industry as new Phd's ..... have very little conception of what goes on in industry and are, in many cases, ill-suited to make a contribution to a business organization. If employed, they tend to suffer form anxiety on two fronts. The source of one anxiety is their traditional graduate training in psychology which makes them feel compelled to be rigorous empiricists, laboratory experimenters, frequent publishers and so forth. On 
the other hand, they seem terrified by the world into which they have come. They readily accept management's ideas about what is wrong with the organization. They too easily accept definitions of problems from others. They uncritically adopt criteria which are probably far more fallacious than the test which they might administer to predict those criteria and so forth."

University training which instills specialized knowledge concerning industrial psychology without thought to its application is not enough. Courses in industrial psychology, even at undergraduate level should be made relevant to the practical situation and the difficulties to be encountered in implementation. To state the ideal without warning that there are obstacles to achieving the ideal is to ensure that graduates soon become disillusioned and frustrated people in practice. Lecturers should themselves be acquainted with some of the practical difficulties and should aim to spend some time in organizations other than their own each year.

Sub-courses in negotiating principles, approaches and techniques should become compulsory for post graduate students and perhaps an elaboration of the present system of intership will assist in developing well rounded and sensitized industrial psychologists for the future.

The second element of the suggested action plan is directed toward creating a general managerial awareness of the limits of amateur industrial psychologists.

In much the same way as Commercial Law I and II are not intended to make attorneys out of commerce students, Industrial Psychology I, II and III are not intended to produce personnel managers or even fully fledged industrial psychologists. Such training should, however, ensure that the individual who later occupies a managerial position avoids making basic mistakes and at the same time knows when to call in the expert industrial psychologist. The commerce faculties of many universities already make compulsory at least one course in industrial psychology for a Bachelor of Commerce degree. This is an encouraging sign and should be extended with a view to making future generations of managers aware of industrial psychology's place in the organizational setup and its potential contribution to organizational effectiveness.

The third element is the strengthening of the existing governing body for the profession of industrial psychology, with well publicized standards of entry. Important steps have al- 
ready been taken in South Africa in this regard. Taken together with elements one and two, this step should facilitate greater mobility of industrial psychologists between organizations and a greater use of consultants in the field. This would enable individual practitioners to adhere more closely to professional norms rather than company objectives but at the same time enhance the receptiveness of top management to suggested changes in their objectives.

In a nutshell, expert power must be created where little now exists In conclusion, it can be submitted that, properly used, the industrial psychologist is the gateway to a scientific, universalistic approach to the effective employment op people and to the continued matching of the organization with its dynamic task environments. The content of industrial psychology indicates, particularly through motivation studies and related organization climate theories that such employment and environmental matching will not only be in the interest of the organization's "fitness for the future" but also contribute to the happiness and satisfaction of all concerned.

\section{SUMMARY}

The South African industrial psychologist is in a quandary; circumstances have deemed that for the most part he be a paid employee of a large organization and subject to the political pressures inherent in such a situation which can challenge the professional integrity of even the strongest practitioner. The situation demands a frank appraisal of the alternatives open to him. Using professionalism as a reference point this article explores the nature of the problems encountered by the industrial psychologist employed in an organizational setting the changing nature of his ultimate role within that structure and a definition of the additional knowledge and skills required to equip him for effective functioning. In conclusion consideration is given to some changes which might be introduced to the teaching programme for new entrants to the profession.

\section{REFERENCES}

Bass, B.M. The role of the business school. Personnel Psychology, 1970, 23(1), 208-221. Cyert, R.M. \& March, J.G. A Behavioral Theory of the Firm. New Jersey: Prentice Hall, 1963.

Garton, G. The History and Science and the New Humanism. New York: Braziller, 1956.

Kornhauser, W. Scientists in Industry Conflict and Accommodation. California: University of California Press, 1963.

March, J.G. \& Simon, H.A. Organizations. New York: Wiley, 1958.

Parson, T. Some aspects of the relation between social science and ethics. 
In Barber, B. \& Hirsch, W. The Sociology of a Science. New York: Free Press of Glencoe, 1962.

Schein, E.H. Professional Education. New York: McGraw-Hill, 1972.

Shepard, H.A. Nine dilemmas in industrial research. In Barber, B. and Hirsch, W. The Sociology of a Science. New York: Free Press of Glencoe, 1962.

Shils, E.A. The autonomy of science. In Barber, B. \& Hirsch, W. The Sociology of a Science. New York: Free Press of Glencoe, 1962.

Thompson, J.D. Organizations in Action. New York: McGraw-Hill, 1967. 